\title{
The occurrence and successful veterinary management of twinning in the thoroughbred mare
}

\author{
R.E.S. Greenwood \\ Greenwood Ellis and partners, Newmarket
}

\begin{abstract}
Summary
During the past 15 years the diagnosed twin conception rate in the Thoroughbred mare population of the Newmarket area of England has risen from 2.1 to $7.2 \%$. Coincidentally, the success rate of converting twin conceptuses to an ongoing singleton pregnancy by early diagnosis and manual rupture of one conceptus has risen to as high as $96 \%$, thereby turning twinning from a significant to an insignificant cause of pregnancy wastage in the breed.
\end{abstract}

Keywords: $\quad$ Conceptus, singleton, twin, crush, mare

\begin{abstract}
Vorkommen und erfolgreiches veterinärmedizinisches Management von Zwillingsträchtigkeiten bei Voliblutzuchtstuten
In den zurückliegenden 15 Jahren stieg die Rate von diagnostizierten Zwillingsträchtigkeiten bei Vollblutstuten im Zuchtgebiet von Newmarket (GB) von 2,1 auf 7,2\%. Gleichzeitig konnte die Erfolgsquote tierärztlicher Maßnahmen bei der Reduktion einer Zwillings- auf eine Einlingsträchtigkeit bis auf $96 \%$ verbessert werden. Der Grund hierfür liegt in den verbesserten Möglichkeiten einer frühzeitigen Diagnose, gefolgt von rechtzeitig durchgeführten Therapiemaßnahmen. Diese Entwicklung führte zu einer weitgehenden Reduktion des ursprünglichen Problems „Zwillingträchtigkeit“ als Ursache für Graviditätsstörungen bei der Stute
\end{abstract}

Schlüsselwörter: Konzeptus, Einlingsgravidität, Zwillingsgravidität, Stute

\section{Introduction}

It appears that Thoroughbreds exhibit a higher rate of twin conception than other breeds. For example, Bowman (1986) reported a twin pregnancy rate of $15.4 \%$ in Thoroughbreds compared to only $6.1 \%$ in standardbreds. Twin pregnancy can cause severe economic loss from abortions, reduced fertility in the following breeding season or the birth of weak and growth-retarded foals. In a survey of the reproductive statistics of the population of Thoroughbred mares in Newmarket during the 1982 and 1983 breeding seasons, the overall incidence of twin conception was 2.1\% (Sanderson and Allen, 1987). In a similar study conducted during the 1998 breeding season, the incidence of twins had risen to $7.2 \%$. This increase is likely to be due to earlier and more accurate pregnancy diagnosis using modern scanners with 5.0 and $7.5 \mathrm{MHz}$ transducers. It also demonstrates the natural tendency for spontaneous reduction of twin conceptuses at this early stage.

This paper describes the management and treatment options applied to twin pregnancies in one large equine stud veterinary practice in Newmarket that deals almost exclusively with Thoroughbred mares.

\section{Materials and methods}

The equipment used for routine ultrasound scanning for pregnancy diagnosis is a 210 or a 500 model Aloca realtime scanner with a $5 \mathrm{MHz}$ linear array transducer. (BCF Technology, Livingstone, Scotland). The majority of mares are scanned under optimum conditions, with good restraint in stocks and in subdued light. They are first scanned on day 15 or 16 after ovulation (usually day 17 after the last mating) when the conceptus is still fully mobile within the uterine lumen (Ginther, 1987). Around $65 \%$ of the twins diagnosed lie adjacent to each other in the same uterine horn (unicornuate), while the other 35\% have one conceptus in each horn (bicornuate).

Bicornuate twins: After careful scanning across the whole uterus one conceptus, usually the smaller, is selected to be crushed. By carefully manipulating and massaging it with the transducer, it is moved towards the tip of the uterine horn where it is ruptured by applying pressure with the transducer while anchoring the conceptus between the fingers against the brim of the pelvis. If, due to asynchronous ovulations, one of the conceptuses is $<10 \mathrm{~mm}$ in diameter it may be so difficult to rupture it is better left alone for 24-48 $\mathrm{h}$ before trying again. Occasionally, the second conceptus is in the body of the uterus where it is usually more difficult to rupture. Accordingly, it may be preferable to massage this conceptus back into a uterine horn, or leave the mare alone for a further $24 \mathrm{~h}$ before trying again. All mares are re-examined $48 \mathrm{~h}$ after a crushing attempt to confirm that reduction has occurred and the remaining conceptus is still viable.

Unicornuate twins: Ideally, these should be separated by gentle massage before attempting to rupture one of them. Hence, it is important to diagnose their existence before the increase in uterine tone around day 17 after ovulation causes their fixation (Ginther, 1987). Separation is helped by sedating the mare with detomidine hydrochloride (Do- 
mosedan, SmithKline Beecham), which both quietens the mare and reduces uterine tone so as to facilitate the separation process. When the conceptuses have separated one can be selected and ruptured as for bicornuate twins. If, however, diagnosis of the twins is not made until after fixation has occurred, steadily increasing pressure on the contiguous conceptuses will often rupture only one. Some damage may be inflicted on the other, thereby, reducing the survival rate to $50-70 \%$, depending upon the stage of gestation at which the manipulation is carried out. An alternative option is to leave the mare alone until day 28 to allow a chance for the natural reduction mechansims described by Ginther (1987) to kill one embryo by starvation occasioned by juxtaposition of the choriovitelline absorptive portion of its conceptus membranes with its co-twin. If both conceptuses are still present at day 28, manual pressure to cause rupture of one of them can be attempted with a $50 \%$ success rate. In any event, reduction by whatever means, or elimination of both conceptuses, must be completed before day 35-36 when the maternal endometrium is invaded by the fetal chorionic girdle cells to form the gonadotrophin (eCG)-secreting endometrial cups (Allen et al, 1973).

Endometrial cysts: Early diagnosis of pregnancy may be complicated by the presence of fluid-filled endometrial cysts in the uterine lumen. These can develop at any stage but they occur most commonly in mares $>10$ years old and their incidence increases with the increasing age of the mare. Although most cysts can be distinguished from a conceptus by the relative thickness of their walls, their nonmotility before day 16 after ovulation, an inappropriate size, a roughened outline, or a lobulated morphology, some cysts can look remarkably like a conceptus. If a cyst is suspected, attempted squeezing must be delaying until diagnosis of the cyst is confirmed by non-appearance of an embryonic heartbeat around day 24. In older mares with multiple cysts, additional examinations may have to be made right up to day 32 to confirm a diagnosis. Recording the existence of cysts prior to mating is helpful but not completely reliable as new cysts can appear quite suddenly and existing cysts may increase in size. All mares are rescanned around day 28-30 for confirmation of the presence of a viable embryo and to exclude any chance of "missed twins".

\section{Results and discussion}

Table 1 compares the singleton and twin conception rates recorded in the two large surveys of Thoroughbred mares in Newmarket; namely, in the 4653 oestrous cycles exhibited by 2670 maiden, barren and foaling mares during the 1982 and 1983 breeding seasons (Sanderson and Allen, 1987) and the 1316 oestrous cycles exhibited by 842 mares 15 years later in 1998. In both surveys, singleton conception rates were higher in the maiden and foaling mares than in the barren mares and, conversely, twin conception rates were higher in the barren mares than in either the maiden or foaling mares. Furthermore, twin conception rate in the barren mares rose from $3.4 \%$ in $1982 / 83$ to $12.2 \%$ in 1998 and, in all the mares, from $2.1 \%$ in $1982 / 83$ to $7.2 \%$ in 1998 . Singleton and twin conception rates both declined with increasing ages of the mare yet, curiously, the detected twin ovulation rate was highest in the oldest mares (>18 years) in the 1998 study.

As shown in Figure 1, attempted rupture of one conceptus achieved an overall success rate of $96 \%$ in the 72 sets of twins on which it was practiced in 1998, with no marked fall off in success in the few cases in which rupture was attempted beyond day 16 after ovulation. Nonetheless, the great majority of rupture attempts were made prior to day 17 when the conceptuses were still freely mobile in the uterine lumen and could be separated with ease.

Tab. 1: Comparison of singleton and twin conception rates of Thoroughbred mares in Newmarket in 1982/83 and 1998.

Vergleich der Raten diagnostizierter Einlings- und Zwillingsträchtigkeit bei Warmblutstuten in Newmarket 1982/83 und 1998.

\begin{tabular}{|l|c|c|c|c|}
\hline & \multicolumn{3}{|c|}{1982 and 1983 breeding seasons combined } \\
& $\begin{array}{c}\text { No. mated } \\
\text { oestrous } \\
\text { periods }\end{array}$ & $\begin{array}{c}\text { Twin } \\
\text { ovulation } \\
\text { rate (\%) }\end{array}$ & $\begin{array}{c}\text { Singleton } \\
\text { conception } \\
\text { rate (\%) }\end{array}$ & $\begin{array}{c}\text { Twin } \\
\text { conception } \\
\text { rate (\%) }\end{array}$ \\
\hline Mare Status & & 16.2 & 51.4 & 2.0 \\
Maiden & 543 & 20.5 & 44.9 & 3.4 \\
Barren & 1255 & 13.7 & 54.0 & 1.6 \\
Foaling & 2855 & & & 2.1 \\
\hline Total/overall & 4653 & & & \\
\hline $\begin{array}{l}\text { Mare age } \\
\text { (years) }\end{array}$ & & 15.0 & 54.7 & 1.9 \\
\multicolumn{1}{|c|}{ 3-8 } & 2393 & 13.7 & 51.8 & 3.1 \\
14-18 & 1372 & 17.7 & 43.0 & 1.5 \\
$>18$ & 719 & 15.1 & 31.4 & 0.6 \\
\hline
\end{tabular}

\begin{tabular}{|l|c|c|c|c|}
\hline & \multicolumn{3}{|c|}{1998 breeding season } \\
& $\begin{array}{c}\text { No. mated } \\
\text { oestrous } \\
\text { periods }\end{array}$ & $\begin{array}{c}\text { Twin } \\
\text { ovulation } \\
\text { rate (\%) }\end{array}$ & $\begin{array}{c}\text { Singleton } \\
\text { conception } \\
\text { rate (\%) }\end{array}$ & $\begin{array}{c}\text { Twin } \\
\text { conception } \\
\text { rate (\%) }\end{array}$ \\
\hline Mare Status & & & & \\
Maiden & 185 & 16.2 & 56.8 & 4.3 \\
Barren & 271 & 24.7 & 41.7 & 12.2 \\
Foaling & 860 & 10.1 & 53.5 & 6.3 \\
\hline Total/overall & 1316 & & & 7.2 \\
\hline Mare age & & & & \\
(years) & & & & \\
3-8 & 619 & 12.4 & 53.0 & 6.5 \\
9-13 & 372 & 9.4 & 51.6 & 8.3 \\
14-18 & 265 & 20.0 & 41.5 & 8.3 \\
$>18$ & 70 & 22.9 & 40.0 & 4.3 \\
\hline
\end{tabular}


Baypamun ${ }^{\oplus} \mathbf{P}$ für Pferde.

\section{Zusammensetzung:}

Eine Dosis (2 ml) enthält nach Resuspendierung: Parapoxvirus ovis Stamm

D 1701 (chemisch inaktiviert) mindestens $10^{6.45} \mathrm{GKID}_{50}$, Polygeline als Stabilisator 50,0 mg. Wirtssystem: permanente Rindernierenzelle.

\section{Anwendungsgebiete:}

Prophylaxe, Metaphylaxe und Therapie von Infektionskrankheiten sowie Verhinderung streßinduzierter Krankheiten bei Pferden durch Stimulierung und Steigerung der körpereigenen, erregerunspezifischen Abwehrkräfte (Paramunisierung).

Gegenanzeigen: Keine bekannt.

\section{Nebenwirkungen:}

Nach der Applikation kann an der Injektionsstelle in seltenen Fällen eine Schwellung auftreten, die in kurzer Zeit wieder resorbiert wird.

Wartezeiten: Keine.

\section{Zusatzinformation:}

Baypamun P ist auch unter dem Entwicklungsnamen PIND ORF bekannt.

Besonders bewährt hat sich der Einsatz von Baypamun $\mathrm{P}$ zur Verhinderung von Infektionen in der Neugeborenen- und in der Absetzphase ebenso wie im Problemkreis der Atemwegs-Infektionen.

Die Mehrfachanwendung von Baypamun $P$ - auch in kurzen Zeitabständen - erlaubt die Stimulierung und die Persistenz des Zustandes der Paramunität über den jeweils erforderlichen Zeitraum ohne Wirkungsverlust.

\section{Verschreibungspflichtig.}

\section{Bayer Vital $\mathrm{GmbH}$ \& Co. KG}

51368 Leverkusen

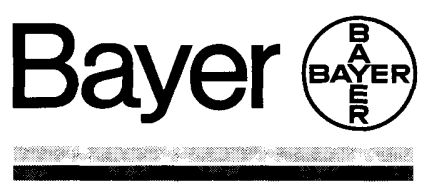

Bayer Vital GmbH \& Co. KG
Since the introduction of ultrasound scanning for early pregnancy diagnosis into the veterinary management of Thoroughbred breeding in the early 1980's (Palmer and Driancourt, 1980, Simpson et al, 1982), this remarkable increase that has occurred in converting twins into an on-

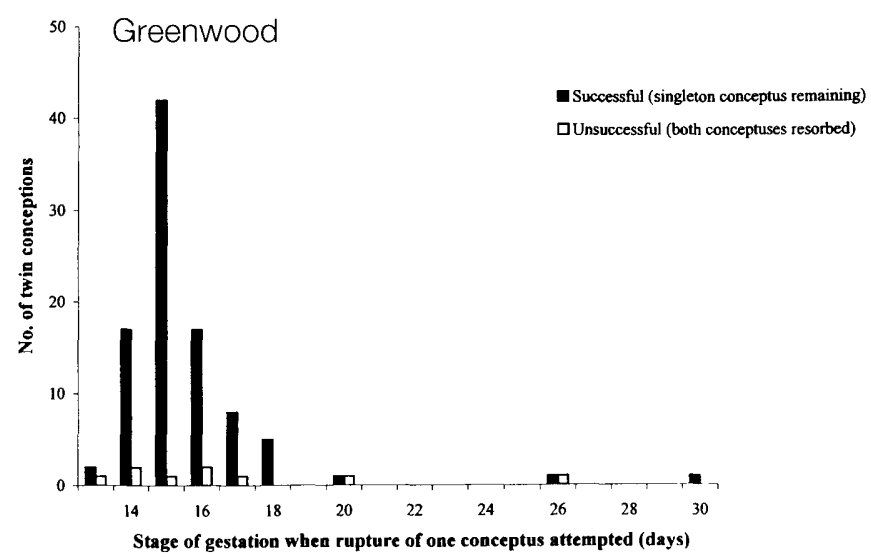

Fig. 1: Success rate of the treatment of twin conceptuses related to the stage of gestation.

Erfolgsquote der Therapiemaßnahmen bei Zwillingsträchtigkeiten in Abhängigkeit vom Gestationszeitpunkt.

going singleton pregnancy by early manual rupture of one conceptus has relegated twinning from being formerly a major to nowadays constituting a very minor cause of barrenness in mares. But this short-term success is tempered in the longer-term by the inevitable increase in twin conception rate that must occur in the breed due to the higher survival rate of fillies conceived as one of twins or triplets and which may be reasonably assumed to be carrying any genes that are associated with the twinning process.

\section{Literature}

Allen, W.R., Hamilton, D.W and Moor, R.M. (1973) The origin of equine endometrial cups. II Invasion of the endometrium by trophoblast. Anal. Rec., 177, 475-501.

Bowman, T. (1986) Ultrasonic diagnosis and management of early twins in the mare. Proc. Am. Assoc. Equine Pract. pp 35-43.

Ginther, O.J. (1987) Relationships among number of days between multiple ovulations, number of embryos and type of embryo fixation in mares. J. equine Vet. Sci., 7, 82-88.

Palmer, E. and Driancourt, M.A. (1980) Use of ultrasonic echography in equine gynaecology. Theriogenology ,13, 203-216.

Sanderson, M.W. and Allen, W.R. (1987) Reproductive efficiency of Thoroughbred mares in the United Kingdom. Proc. 9th Bain-Fallon Memorial Lectures. Ed. P. Huntington pp. 31-41. Australian Equine Veterinary Association, Sydney.

Simpson, D.J., Greenwood, R.E.S., Ricketts, S.W., Rossdale, P.D., Sanderson, M. and Allen, W.R. (1982) Use of ultrasound echography for early diagnosis of single and twin pregnancy in the mare. $J$. Reprod. Fert., Suppl. 32, 431-439.

Greenwood, Ellis and partners

Reynolds House,

High Street, Newmarket,

Suffolk CB8 9AH, UK. 